\title{
Complex regional pain syndrome in the orofacial region. Case report
}

\author{
Síndrome complexa de dor regional em região orofacial. Relato de caso
}

Elba Lúcia Wanderley Santos ${ }^{1}$, Igor Santos Sales², Nadja Maria Jorge Asano¹, Maria das Graças Wanderley de Sales Coriolano

DOI 10.5935/2595-0118.20180071

\section{ABSTRACT}

BACKGROUND AND OBJECTIVES: The complex regional pain syndrome is characterized by presenting autonomic, sensory and motor difficult to control changes of the chronic evolution. Its pathophysiology and treatment are not fully defined, and the search for an increasingly effective treatment is a subject of medical concern. The involvement of the orofacial region has an even rarer incidence, and the literature reports only 14 cases in five decades. The objective of this report was to warn physicians and researchers about the importance of a correct diagnosis and to show the possibility of controlling this dysfunction with conservative treatment.

CASE REPORT: A 68-year-old female patient, who after a facial trauma and three subsequent surgical procedures, developed orofacial complex regional pain syndrome. Several therapeutic regimens were performed, and after the last one she became completely asymptomatic: oxcarbazepine $(900 \mathrm{mg} / \mathrm{day})$, morphine-controlled liberation $(120 \mathrm{mg} /$ day), fluoxetine $(40 \mathrm{mg} /$ day) and clonazepam ( $2 \mathrm{mg} /$ day), electrotherapy and oral rehabilitation.

CONCLUSION: The diagnosis criteria for complex regional pain syndrome recommended by the International Association for the Study of Pain, revised in 2007, should be followed. The treatment of this neuropathic syndrome includes anticonvulsants, tricyclics, opioids, electrotherapy and somatic and stellate ganglion block, the latter when the pain is maintained by the sympathetic nervous system. In this report of an orofacial complex regional pain syndrome II, pain control was shown without the need for sympathetic ganglion block, which can be a warning to the medical class to a correct diagnosis and an effective and less invasive treatment.

Keywords: Algodystrophy, Causalgia, Diagnosis, Facial pain, Reflex sympathetic dystrophy, Therapeutics.

1. Universidade Federal de Pernambuco, Recife, PE, Brasil.

2. Universidade Católica de Pernambuco, Faculdade de Medicina, Recife, PE, Brasil.

Submitted on May 16, 2018.

Accepted for publication on September 04, 2018.

Conflict of interests: none - Sponsoring sources: none.

Correspondence to:

Ambulatório de Dor e Acupuntura

Av. Prof. Moraes Rego, 1235 - Cidade Universitária

50670-901 Recife, PE, Brasil.

E-mail: gracawander@hotmail.com

(C) Sociedade Brasileira para o Estudo da Dor

\section{RESUMO}

JUSTIFICATIVA E OBJETIVOS: A síndrome complexa de dor regional se caracteriza por apresentar alteraçóes autonômicas, sensitivas e motoras de evolução crônica de difícil controle. Sua fisiopatologia não está totalmente definida e a busca por um tratamento cada vez mais eficaz é objeto de preocupação médica. $\mathrm{O}$ comprometimento da região orofacial tem uma incidência ainda mais rara e a literatura relata apenas 14 casos em cinco décadas. O objetivo deste relato foi alertar médicos e pesquisadores para a importância de um diagnóstico correto e mostrar a possibilidade de controle dessa disfunção com o tratamento conservador.

RELATO DO CASO: Paciente do sexo feminino, 68 anos, após trauma facial e três intervençôes cirúrgicas posteriores, desenvolveu quadro de síndrome complexa de dor regional orofacial. Foram realizados vários esquemas terapêuticos, o último dos quais tornou-a completamente assintomática: oxcarbazepina $(900 \mathrm{mg} / \mathrm{dia})$, morfina de liberação controlada $(120 \mathrm{mg} / \mathrm{dia})$, fluoxetina $(40 \mathrm{mg} / \mathrm{dia})$ e clonazepam $(2 \mathrm{mg} / \mathrm{dia})$, eletroterapia e reabilitação oral.

CONCLUSÁO: Os critérios de diagnóstico para a síndrome complexa de dor regional, preconizados pela International Association for the Study of Pain, revisados em 2007, devem ser seguidos. O tratamento desta síndrome neuropática inclui anticonvulsivantes, tricíclicos e opioides, eletroterapia, bloqueio somático e de gânglio estrelado, este último quando a dor for mantida pelo sistema nervoso simpático. Neste relato de uma síndrome complexa de dor regional II orofacial foi mostrado o controle da dor sem a necessidade de bloqueio do gânglio simpático, o que pode alertar a classe médica para um correto diagnóstico e um tratamento eficaz e menos invasivo.

Descritores: Algodistrofia, Causalgia, Diagnóstico, Distrofia simpática reflexa, Dor orofacial, Terapêutica.

\section{INTRODUCTION}

Complex regional pain syndrome (CRPS) is characterized by autonomic, sensory and motor alterations of chronic evolution. It is a disease of difficult control whose pathophysiology is not totally defined, causing concern to the health professionals, in the search for an increasingly effective treatment. The involvement of the orofacial region has an even rarer incidence, as shown in a systematic review conducted from 1947 to 2010, with only 14 published cases. Thus, more research and scientific publications are necessary for a better understanding, precise diagnosis and effective treatment of this phenomenology ${ }^{1}$.

This orofacial syndrome originates after local tissue lesions, traumas such as difficult dental extractions, accidents with sharp and 
blunt instruments, post-surgeries, or even systemic diseases. It affects more males, with an average age of 45.5 years old. The disease is classified into two types: CRPS type I, also called reflex sympathetic dystrophy and CRPS type II, also called causalgia ${ }^{2}$. The clinical picture of this syndrome in the orofacial region may vary from patient to patient. Pain usually compromises the topography innervated by the local sympathetic system that accompanies the vascular system of this area, comprising regions of the dermatomes ${ }^{1,3}$. In addition, the patient may present other local alterations, such as changes in color and skin temperature, hypersalivation, and, in some rare cases, trophic alterations and local skin edema ${ }^{2}$. Unlike the CRPS type I of the extremities, which presents with profound tissue, vascular and trophic alterations, these alterations are not reported in this orofacial syndrome ${ }^{1}$.

The pathophysiology is controversial, but alterations can occur in the effector organ, in the peripheral afferent fiber, in the sympathetic neuron, in the spinal cord, and in the supraspinal centers. The main theory about the origin of this disease indicates changes in the reception, transduction, modulation and perception of pain, in which the fibers A-delta and C suffer changes and exacerbate their activities, causing disproportionate distortions in the characterization and feeling of pain reported by the patient. An exaggerated inflammatory response, aberrant healing ${ }^{4}$, neuroma formation, a disorganized structure with spontaneous nociceptive impulses by local biochemical alterations lead to a distortion of the transmission process and pain modulation ${ }^{5}$.

The diagnosis is purely clinical. The criteria of the International Association for the Study of Pain (IASP) (1994), revised in 2007 for the diagnosis of CRPS should be followed, noting that orofacial CRPS is a rare and difficult diagnosis and treatment entity ${ }^{6}$. This report aimed to alert doctors and researchers to the importance of a correct diagnosis and to show the possibility of controlling this dysfunction with conservative treatment.

\section{CASE REPORT}

A 68-year-old female patient reported falling from her own height three months ago, with a small lesion on the lower lip, close to the left labial commissure. From this trauma, she began a pain that lasted even after the healing process. The pain was continuous, of intensity $8 / 9$ by visual analog scale (VAS). The patient reported a sensation of foreign body in the place, with edema and difficulty to speak. At examination, the lower lip presented mild edema and hyperesthesia. She was submitted to image examinations: ultrasound (USG) and computed tomography (CT) of the lips, to investigate foreign body, but nothing was detected, only image compatible with fibrotic tissue.

Initially, the diagnostic hypothesis of post-trauma neuropathic chronic pain was established for possible neuroma and prescribed: gabapentin $(300 \mathrm{mg}) 1 \mathrm{tablet}$ every $12 \mathrm{~h}$ and codeine (30mg) 1 tablet every $8 \mathrm{~h}$ and amitriptyline $(25 \mathrm{mg})$ that the patient had used for 3 years for the treatment of post-herpetic neuralgia on the lateral side $\mathrm{D}$ of the thorax was maintained, which is currently controlled. There was no relief for facial pain. After 10 months, the patient returned to the Hospital das Clínicas, with a history of surgical intervention at the pain site, in a private institution. Excision of the hardened pain region was performed, and histopathological examination showed fibrotic tissue.

After this first intervention, the pain was severe, spontaneous, continuous, accompanied now by burning and mechanical allodynia. Pharmacological treatment was initiated: amitriptyline $(25 \mathrm{mg} /$ day), gabapentin $(300 \mathrm{mg})$ every $8 \mathrm{~h}$, clonazepam $(2 \mathrm{mg})$ was introduced at night, fluoxetine (20mg) daily for anxiety, depressive symptoms and sleep disorders resulting from pain chronic. Codeine was replaced by tramadol $(50 \mathrm{mg})$ every 6 hours, associated with acupuncture treatment. An improvement of around $40 \%$ was observed in pain.

In the search for a quick solution to her problem, the patient underwent two more surgical interventions, which further aggravated her pain and her suffering. She complained at the time of pain with VAS 9/10, local burn and heat, edema that worsened when she spoke, with distortion of the oral anatomy, difficulty in chewing solids. The examination revealed: local temperature increase, hyperesthesia, hyperalgesia and mechanical allodynia in the topographically exact region of the traumas.

An orofacial CRPS was diagnosed, consequent to the successive traumas in the level of the peripheral facial sensory pathways. Thus, electroacupuncture treatment alternating low and high frequencies was restarted, which generated immediate relief of pain; but after two or three days the pain returned at the same intensity. Methadone $(5 \mathrm{mg}), 1$ tablet every 12 hours (instead of trama$\mathrm{dol})$, and gabapentin were replaced with oxcarbazepine $(300 \mathrm{mg})$ 3 times daily. Amitriptyline was progressively withdrawn to avoid possible adverse effects because she is an elderly patient.

With this therapeutic scheme, the patient was completely asymptomatic for up to 24 hours. Unfortunately, she began to present adverse effects to methadone, such as accentuated edema in the lower limbs and oliguria. Thus, methadone was replaced by simple morphine (10mg) every $6 \mathrm{~h}$, provided by the service. Rescue in episodic pain with $5 \mathrm{mg}$ of morphine was performed until it became asymptomatic, and the daily dose was replaced by controlled release morphine (CR), $60 \mathrm{mg}$ every $12 \mathrm{~h}$ and beginning of oral rehabilitation.

At the moment, the patient is almost asymptomatic. She refers only to pain in weight, VAS $2 / 3$, when she talks more during the day. Using morphine CR $(60 \mathrm{mg})$ every $12 \mathrm{~h}$, oxcarbazepine $(600 \mathrm{mg})$ at night and 300mg in the morning. She has improved depression with fluoxetine ( $40 \mathrm{mg} /$ day) and clonazepam $(2 \mathrm{mg}), 1$ tablet at night.

\section{DISCUSSION}

It is notorious that orofacial CRPS is a challenging case because of the scarcity of specific and sufficient scientific literature to direct its proper handling and understanding.

The diagnostic criteria for CRPS, as recommended by the IASP, reviewed at a congress held in Budapest ${ }^{7.8}$ are classified based on four items. 1) Continuous pain, disproportional to any event-incident; 2) Presence of a symptom among the following four categories: a) sensorial: hyperesthesia and/or allodynia; b) vasomotor: temperature asymmetry and/or changes in skin color and/ or asymmetry of skin color; c) sudomotor/edema: edema and/or transpiration changes and/or smoothing of asymmetry; d) mo- 
tor/trophic: decreased range of motion and/or dysfunction and/ or trophic changes; 3) exhibit at least one sign at the time of assessment between two or more of the following categories: a) sensorial: hyperalgesia and/or allodynia, b) vasomotor: evidence of temperature asymmetry $\left(>1^{\circ} \mathrm{C}\right)$ and/or changes in skin color and/or asymmetry; c) sudomotor/edema: evidence of edema and/or changes in sweating and/or smoothing of asymmetry; $d$ ) motor/trophic: evidence of a decrease in range of motion and/ or motor dysfunction and/or trophic changes; and 4) There is no other diagnosis that better explains the signs and symptoms. The patient fulfilled the 4 items of the diagnostic criteria recommended by the IASP and reviewed in 2007. Pain triggered after several noxious events on the lower lip, on the left; the presence of continuous, spontaneous severe pain (VAS 9/10), not proportional to the initial triggering event; mechanical allodynia, hyperalgesia, edema, local heat sensation, and distortion of the anatomy, with difficulty to speak. Other diagnostic possibilities of facial pain were excluded, through complementary exams and evaluations with a multidisciplinary team.

In the treatment of these patients, it is fundamental to rehabilitate and relief of pain, with the use of drugs and interventions, such as sympathetic and somatic blockade?

In pharmacological treatment, opioids may be used, which should follow the protocol for chronic non-oncologic pain ${ }^{10}$. Tricyclic antidepressants have proven their efficacy in modulating chronic pain by various mechanisms, notably blockade of serotonin and noradrenaline receptors. Anticonvulsants, by stabilizing the sodium, calcium and potassium channels. Gabapentin has been shown to be effective in the treatment of this syndrome ${ }^{11-13}$. Carbamazepine is also indicated for neuropathic pain in the head and neck region ${ }^{14}$. Blockade of the somatic nerve or sympathetic ganglion is performed in more complex and refractory cases of the syndrome ${ }^{3}$. One of the non-pharmacological treatments described in the literature is the use of electrostimulation, such as transcutaneous electrical nerve stimulation, percutaneous nerve stimulation (electroacupuncture), or even biofeedback, but few studies have validated the use of these techniques ${ }^{11}$.

In this report, the treatment consisted of electroacupuncture alternating low and high frequencies, which allows the release of different opioid neurotransmitters at the central level, with an inhibitory and modulatory effect of chronic pain ${ }^{15}$. Opioids (morphine CR) and anticonvulsant (oxcarbazepine) were given, considering that the opioid can be used when other therapeutic measures fail, and the patient did not respond to the first line anticonvulsant indicated in the literature ${ }^{16}$. The selective serotonin reuptake antidepressant was used for emotional stabilization. The patient improved by $80 \%$, requiring no sympathetic stellate ganglion blockade, possibly because it was CRPS type II'. Oxcarbazepine was more effective than gabapentin ${ }^{16}$.

Heir et al. ${ }^{17}$ observed treatments for this syndrome in two reported cases. In the first, two stellate ganglion blockades were performed, obtaining an improvement of $80 \%$; and in the second, after numerous failures in treatment, it was only possible to abolish the pain with this blockade. According to Melis et al. ${ }^{18}$, the presence of sympathetic reflex signs and symptoms is one of the main indications for the application of ganglionic blockade. Possibly, in the reported cases, there was maintenance of the clinical picture by the sympathetic nervous system, obtaining an optimal response in the control of pain, which was not the case in this report, since it was first chosen by conservative treatment for pain control, considering the patient's age, irreversible complications, and the scientific basis ${ }^{7,18,19}$. Vasomotor and sudomotor changes do not necessarily provide evidence for pain maintained by the sympathetic, but certainly, demonstrate sympathetic involvement ${ }^{20}$.

Sakamoto et al. $^{21}$ reported a case in which the patient was subjected to the most diverse types of pharmacological and non-pharmacological treatments. The most effective was the stellate ganglion blockade, which provided instant and complete pain relief for a few days. The pain returned, and it was necessary to perform the procedure innumerable times, which made it less effective and needed its association with the most diverse treatments. In the period 1996 to 2001, some drugs currently used had not yet been applied in the treatment of CRPS.

\section{CONCLUSION}

This report demonstrated the importance of awareness for the diagnosis of orofacial CRPS, as well as pain control, mainly in type II, adopting a conservative approach.

\section{REFERENCES}

1. Cândido DK, Winnie A. Reflex Sympathetic Dystrophy on the face. Pain management. London: Elsevier; 2011. 506-13p.

2. Cordon FC, Lemonica L. [Complex regional pain syndrome: epidemiology, pathophysiology, clinical manifestations, diagnostic tests and therapeutic proposals]. Rev Bras Anestesiol. 2002;52(5): 618-27. Portuguese.

3. Arden RL, Bahu SJ, Zuazu MA, Berguer R. Reflex sympathetic dystrophy of the face: current treatment recommendations. Laryngoscope.1998;108(3):437-42.

4. Galler BS, Schwartz L, Allen RJ. Complex regional pain syndromes type I: reflex sympathetic dystrophy, and type ii: causalgia. In: Loeser JD (editor). Bonica's management of pain. Philadelphia: Lippincott Williams \& Wilkins; 2001. 388-411p.

5. Raj PP. Reflex sympathetic dystrophy. In: Raj PP (editor). Pain Medicine. St. Louis Mosby; 1996. 466-82p.

6. Hoffmann KD, Matthews MA. Comparison of sympathetic neurons in orofacial and upper extremity nerves: implications for causalgia. J Oral Maxillofac Surg. 1990;48(7):720-7.

7. Harden RN, Bruel S, Stanton-Hicks M, Wilson PR. Proposed new diagnostic criteria for complex regional pain syndrome. Pain Med. 2007;8(4):326-31.

8. Harden RN, Bruehl S, Perez RS, BIirklein F, Marinus J, Maihofner C, et al. Validation of proposed diagnostic criteria (the "Budapest Criteria") for Complex Regional Pain Syndrome. Pain. 2010;150(2):268-74.

9. Stanton-Hicks M. Complex regional pain syndrome. Anesthesiol Clin North America. 2003;21(4):733-44

10. Skaer TL. Practice guidelines transdermal opioids in malignant pain Drugs.2004;64(23):2629-38.

11. Baron R, Binder A, Ludwing J, Schattschneider, Wasner GL. Diagnostic tool and evidence-based treatment of complex regional pain syndrome. In: Iaps Refresher course on Pain Management Pain. Update review: refresher course syllabus. Seatle: IASP; 2005. 293-306p.

12. Rowbotham MC. Pharmacologic management of complex regional pain syndrome. Clin J Pain. 2006;22(5):425-9.

13. Krause HL, Sredni S. Systemic drug therapy for neuropathic pain review. Br J Pain. 2016;17 (Suppl 1):S91-4

14. Alrashood ST. Carbamazepine. Profiles Drug Subst Excip Relat Methodol 2016;41:133-321.

15. Chen XH, Han JS. Analgesia induced by electroacupuncture of different frequencies is mediated by different types of opioid receptors: another cross-tolerance study. Behav Brain Res.1992;47(2):143-9.

16. Lee YH, Lee KM, Kim HG, Kang SK, Auh QS, Hong JP, et al. Orofacial complex regional pain syndrome: pathophysiologic mechanisms and functional MRI. Oral Surg Oral Med Oral Pathol Oral Radiol. 2017;124(2):e164-70.

17. Heir GM, Nasri-Heir C, Thomas D, Puchimada BP, Khan J, Eliav E, et al. Complex regional pain syndrome following trigeminal nerve injury: report of 2 cases. Oral Surg Oral Med Oral Pathol Oral Radiol. 2012;114(6):733-9. 
18. Melis M, Zawawi K, al-Badawi E, Lobo Lobo S, Mehta N. Complex regional pain syndrome in the head and neck: a review of the literature. J Orofac Pain. 2002;16(2):93-104.

19. Janig W. The puzzle of "reflex sympathetic dystrophy": mechanisms, hypothesis, open questions. In: Janig W, Stanton-Hicks M, editors. Reflex Sympathetic Dystrophy: a reappraisal. Seattle: IASP; 1996. 1-24p.
20. Janig W, Baron R. Complex regional pain syndrome: mystery explained? Lancet Neurol. 2003;2(11):687.

21. Sakamoto E, Shiiba S, Noma N, Okada-Ogawa A, Shinozaki T, Kobayashi A, at al A possible case of complex regional pain syndrome in the orofacial region. Pain Med. 2010;11(2):274-80. 